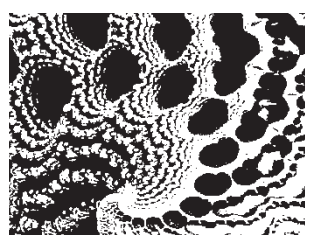

\title{
THE ROLE OF PERSONALITY AND SUBJECT-SPECIFIC MOTIVATION IN STUDENTS' ACHIEVEMENT IN MATH AND MOTHER TONGUE
}

Sonja PEČJAK, Tina PIRC, Cirila PEKLAJ

Faculty of Arts, Ljubliana

UDK: 159.947.5-057.87(497.4):37 373.5.091.212.6(497.4):159.9

Izvorni znanstveni rad

Primljeno: 27. 11. 2015.

The aim of the study was to examine and to compare the relationships of different personality traits, subject-specific motivational dimensions and students' achievement in math and mother tongue in general upper secondary education, as well as how these variables predict their achievement. A total of 397 students attending the first year of general upper secondary education in Slovenia participated in the study. Different measures were used to assess students' personality traits, subject-specific interest, self-efficacy, volitional strategies and final grades in math and mother tongue. The results of the research showed different patterns of achievement predictors in both subjects and differences in the predictive power of included variables according to subjects. The included variables predicted $18 \%$ of variance in the Slovene language and $31 \%$ of variance in math. In both subjects, achievement was significantly positively predicted by self-efficacy and interest, and significantly negatively predicted by energy and procrastination. In math, agreeableness was also found as a significant negative predictor, and in Slovene language conscientiousness and immediate action were found as positive predictors of students' achievement. Implications of the study's findings are also discussed.

Keywords: personality traits, interest, self-efficacy, students, achievement

$\triangle$ Sonja Pečjak, University of Ljubljana, Faculty of Arts, Department of Psychology, Aškerčeva 2, 1000 Ljubljana, SI-Slovenia.

E-mail: sonja.pecjak@ff.uni-li.si 
In Slovenia, most primary school students ${ }^{1}$ continue their education at upper secondary schools, among them $40 \%$ in the general upper secondary programme (Taštanoska, 2014). Math and mother tongue (the Slovene language/L1) are the central general subjects in general upper secondary education, which are obligatory for students throughout the four-year educational programme. These two subjects are the most extensive among all subjects - they comprise 560 hours (140 hours per year). They both have important impact on students' success in all four years of schooling, as well as in the national final exam ("matura"), which represents the admission criterion for further schooling. It is therefore important to understand different factors (personality and motivational) that affect the students' achievement in math and L1 and may help to improve it (Peklaj, Podlesek, \& Pečjak, 2015).

The role of personality traits and motivational dimensions in students' achievement in math has already been investigated relatively well in previous studies (Shams, Mooghali, Tadebordbar, \& Soleimanpour, 2011; Tulis \& Fulmer, 2013), but the research on comparing the roles of these factors in both subjects, as in our study, is scarce (Smrtnik Vitulić \& Zupančič, 2013). We were interested in the comparison of personality traits and motivational dimensions and their roles in students' academic achievement in both subjects. This is especially interesting, because math and L1 have distinctive goals as well as content structure and instruction, and additional knowledge on different effects of personality and motivational factors could be of additional value.

The curriculum of L1 consists of two parts: language and literature courses (Curriculum for the Slovene language, 2008). The main goals of the language courses are understanding the basic language concepts and structures, and developing four communication abilities - listening, speaking, reading and writing. These competences are the basis for effective communication (oral and writing) in school and in private life. The goal in literature courses, however, is to develop experiential, creative and evaluative abilities, which enhance the

1 In Slovenia, there are 9 years of basic/primary education (students, aged 6 to 15 years included) and upper secondary education with 3 years of vocational programmes (students from 15 to 18 years) or with 4 years of technical or general programmes-gymnasium (students from 15 to 19 years). students' personality and personal growth by reading literary texts.

The primary goals of math courses are to understand the basic mathematical concepts and structures; to develop abstract logical thinking, i.e., the ability of mathematical reasoning, by acknowledging mathematical rules and logic; to develop geometrical concepts and to use ICT as a help for effective learning and problem solving (Curriculum for Mathematics, 2008). 
DRUŠ. ISTRAŽ. ZAGREB GOD. 25 (2016), BR. 4 STR. 503-522

PEČJAK, S., PIRC, T. PEKLAJ, C.:

THE ROLE OF.
From the instructional point of view, there are more elective contents in L1, while in math the amount of elective contents is smaller (Curriculum for Mathematics, 2008). Instruction in math is usually more structured, more concerned with activation of relevant previous knowledge in students due to the hierarchical structure of material. In addition, the need for regular exercises (e.g., homework with immediate feedback), is the key to good math achievement. The emphasis in L1 is on group discussion in order to compare and contrast the students' personal experience with the contents considered.

Most previous research on relationships between personality and motivational dimensions and academic achievement was performed in university (Chamorro-Premuzic \& Furnham, 2003; De Feyter, Caers, Vigna, \& Berings, 2012; Komarraju, Karau, \& Schmeck, 2009) or in primary school students (Smrtnik Vitulić \& Zupančič, 2013). To a far lesser extent, these variables were investigated in upper secondary education students (Peklaj et al., 2015), and even then in the final years (Shams et al., 2011; Vasalampi et al., 2014). Therefore, our sample comprised students from the first year of general upper secondary school.

The transition to upper secondary school could be very demanding for students. Teachers have higher expectations for them. They expect higher levels of behaviour control, independent learning and more learning discipline from their students, and students' abilities to meet these expectations are determined by their personality and motivational traits.

Another reason for choosing the first year of general upper secondary school students was the importance of early intervention in this four-year period of schooling for students. Knowing the coexisting effects of personality and motivational factors on students' academic achievement enables successful early interventions (Peklaj et al., 2015).

\section{PERSONALITY TRAITS AND ACADEMIC ACHIEVEMENT}

The Big Five personality factors (energy/extraversion, agreeableness, conscientiousness, emotional instability/neuroticism and openness) capture most of the individual differences in behaviour, also in educational settings (McCrea \& Costa, 1999). In the educational context, the relationship between personality traits and academic achievement is the most commonly explored. Research consistently revealed positive connections between academic achievement and conscientiousness (Chamorro-Premuzic \& Furnham, 2005; Smrtnik Vitulić \& Zupančič, 2013). Conscientious students are characterised by their orderly and precise schoolwork, which leads to better academic achievement (Poropat, 2009). Conscientiousness remains 
DRUŠ. ISTRAŽ. ZAGREB GOD. 25 (2016), BR. 4, STR. 503-522

PEČJAK, S., PIRC, T., PEKLAJ, C. THE ROLE OF.. to be a significant predictor of achievement also after controlling for intelligence (Bratko, Chamorro-Premuzic, \& Saks, 2006; Di Fabio \& Busoni, 2007) or previous knowledge (Poropat, 2009; Trautwein, Lüdtke, Roberts, Schnyder, \& Niggli, 2009).

The results on the relation between academic achievement and other personality traits are not so clear. Some studies show negative impact of neuroticism on school achievement in high school (Laidra, Pullamann, \& Allik, 2007; Chamorro-Premuzic \& Furnham, 2003), while meta-analytic studies in general did not confirm this connection (Poropat, 2009). The research results on the relations between openness to experience and achievement are not consistent either. The majority of research revealed low positive correlations between openness and achievement in high school students (Furham, Monsen, \& Ahmetoglu, 2009; Puklek Levpušček, Zupančič, \& Sočan, 2013), but some other studies found no evidence of this relation (Conard, 2006; Hair \& Hampson, 2006).

In addition, for agreeableness (tendency to be friendly, cooperative, generous, and prepared to compromise), research showed mixed results about its relation to academic achievement. Some studies found it to be a negative predictor of GPA (Di Fabio \& Busoni, 2007), some found no correlation with the GPA (Bratko et al., 2006) or math grade (Smrtnik Vitulić \& Zupančič, 2013), while some found positive correlations with GPA (Laidra et al., 2007).

The personality trait energy/extraversion characterizes dynamic, active students with high energy. Despite the anticipation that this energy might contribute to investment in learning situations, which lead to higher achievement, only a few studies confirmed this assumption (De Raad \& Schouwenburg, 1996). In some studies the relation was negative (Puklek Levpušček et al., 2013; Smrtnik Vitulić \& Zupančič 2013) and in others the connection between extraversion and academic achievement was not found (Di Fabio \& Busoni, 2007).

Inconsistency in the connections between personality traits and GPA could point to the importance of specific learning context/subject, in which these connections were taken under consideration, as explored in our study.

Furthermore, the majority of studies examined the relations between different personality traits and GPA in math, but only a few investigated the connections of students' personality traits with achievement in other subjects, least of all, with the achievement in L1 (Smrtnik Vitulić \& Zupančič, 2013). Therefore, our study was focused on the comparison of the role of personality traits in two different learning subjects - math and L1. 


\section{MOTIVATION AND ACADEMIC ACHIEVEMENT}

Our selection of motivational factors was based on the socio-cognitive theory of learning (Bandura, 1986), which explains that achievement depends on the interaction between the person's behaviour, personal factors (e.g., beliefs, including motivational beliefs) and environmental conditions. This interaction is known as reciprocal determinism. The perception of one's own abilities and successfulness in a given context influences one's behaviour and environment, and vice versa - social environment is supposed to affect individuals' behaviour through their beliefs. Bandura (1986) proposed that students' motivational beliefs about self-efficacy could affect their learning behaviour (motivation and strategies) and their learning results.

Self-efficacy refers to students' beliefs about their ability to learn and master a specific task (Bandura, 1986). It is consistently found to be positively related to student achievement in math (Liem, Lau, \& Nie, 2008; Kenney-Benson, Pomerantz, Ryan, \& Patrick, 2006; Puklek Levpušček \& Zupančič, 2009), reading (Pečjak, Bucik, Gradišar, \& Peklaj, 2006; Pečjak, Kolić Vehovec, \& Podlesek, 2014) and writing (Schunk \& Zimmerman, 2007). Self-efficacy impacts academic achievement through meaningful cognitive engagement - better attention and the use of better (meta)cognitive strategies (Pečjak et al., 2014; Walker, Greene, \& Mansell, 2006), as well as through motivational strategies (De Feyter et al., 2012; Wolters \& Rosenthal, 2000). Students with higher self-efficacy are more persistent with learning assignments and more willing to put in a lot of effort, all of which leads to higher academic achievement.

Interest in $L 1$ includes enjoyment in activities like reading or writing different literary and explanatory texts, speaking in front of the audience and creative writing. Interest in math includes liking math problems, enjoying working on math tasks and curiosity about solutions. Research has consistently showed positive connections between reading and writing interest with achievement in L1 (Guthrie, Wigfield, Metsala, \& Cox, 1999; Hidi, 2001; Schiefele, 2001). It also shows positive connections between math interest and achievement (Köller, Baumert, \& Schnabel, 2001; Lipnevich, MacCann, Krumm, Burrus, \& Roberts, 2011; Schiefele, Krapp, \& Winteler, 1992).

Besides motivational strategies, students' volition to reach the learning goal is also important. Volitional strategies are activities which help students actively direct and regulate the effort to achieve certain goals (Peklaj et al., 2015). They preserve the intention of learning and affect the level of effort and persistence in learning, and enable students to finish their tasks despite the obstacles that might come in the way (Corno, 2001). 
DRUŠ. ISTRAŽ. ZAGREB GOD. 25 (2016), BR. 4, STR. 503-522

PEČJAK, S., PIRC, T., PEKLAJ, C.

THE ROLE OF..
It is also important for students to start with tasks as soon as possible and avoid procrastination, which would prevent them from reaching their goals. Therefore, we included two strategies - immediate action and procrastination/distractibility in our study. In previous studies, immediate action was related to better and procrastination/distractibility to poorer academic achievement (Klassen, Krawchuk, \& Rajani, 2008; Steel, 2007).

\section{Research problem}

The aim of the study was to find out:

1) the relationships of different personality traits, subject-specific motivational dimensions and students' achievement in general upper secondary school in two subjects - math and L1;

2) how these variables predict students' achievement in math and L1. We wanted to find out if there were differences in the effects in both learning contexts.

According to previous studies, the following hypotheses have been developed:

H1) Conscientiousness will be positively connected with achievement in both subjects. We expected higher correlations and stronger predictive power of conscientiousness in math, because hierarchical content structure in this subject demands regular rehearsal.

$\mathrm{H} 2)$ There will be negative correlations between agreeableness, energy and learning achievement in both subjects. We expected both variables to be stronger negative predictors for math achievement, where instruction is more structured and where students cooperate in learning assignments less often than in L1.

H3) Self-efficacy, interest and immediate action will be positive predictors of achievement, and procrastination will be a negative predictor of academic achievement in both subjects.

\section{METHOD}

\section{Participants}

A total of 397 general upper secondary school students (145 boys and 252 girls) in their first grade of general upper secondary education participated in the study. Students were recruited from 13 different classrooms distributed across six selected schools in different regions of Slovenia. Their average age was 15.67 years $(S D=0.34)$. 


\section{Instruments and procedures}

Big Five Inventory - BFI (John, Donahue, \& Kentle, 1991) for measuring personality traits. It consists of 44 items, which represent the most prototypical traits that define five domains: energy (extraversion, 8 items), agreeableness (9 items), conscientiousness (9 items), emotional instability (neuroticism, 8 items) and openness (10 items). Students were asked to indicate how much each statement applied to them on a 5-point scale (from 1 - strongly disagree to 5 - strongly agree). Cronbach's alpha coefficients for scales in our study were: $0.72,0.76,0.78,0.74$ and 0.75 , respectively.

Volitional strategies scale included 12 items adapted from Self-Regulation Inventory SSI-K3 (Kuhl \& Fuhrmann, 2004). Students indicated the extent to which the statements applied to them on a 4-point scale (from 1 - not at all to 4-completely). Exploratory factor analysis (principal component analysis; oblimin rotation) revealed two factors: immediate action (4 items; If something must be done, I begin doing it without hesitating.; $\alpha=0.78$ ) and procrastination/distractibility ( 8 items; I postpone many things that I have to do.; $\alpha=0.90$ ).

Self-efficacy scale with 5 items was taken from PALS (Patterns of Adaptive Learning Scale, Midgley et al., 2000). It was adapted for mathematics and L1 and used to measure the students' math and L1 self-efficacy (for math: I'm certain I can master skills taught in math class this year.; for L1: I can do even the hardest work in mother tongue class if I try.) Students responded to items on a 5-point scale (1 - not at all true, 5 - very true). Cronbach's alpha coefficient in our study for math scale was 0.78 and for L1 scale 0.87 .

Interest in mathematics scale and Interest in Slovene scale were adopted from the Questionnaire about Learning in Mathematics - QLM and Questionnaire about Learning in Slovene-QLS (Peklaj \& Vodopivec, 1998). Both consisted of 5 items and measured the individual student's interest in math and L1 (e.g., I find the learning content of math interesting. I like the subject of Slovenian language.). Students reported their attitudes toward math and L1 on a 5-point Likert scale (1 - strongly disagree, 5 - strongly agree). Cronbach's alpha coefficient for math was 0.89 and for L1 0.83 .

Final math or L1 grades at the end of the school year were used as a measure of the students' math and mother tongue achievement. The final grade represents the average of students' math/L1 grades over the school year. In Slovenia, grades have the following meaning: 1 - not sufficient, 2 - sufficient, 3 - good, 4 - very good, 5 - excellent knowledge.

Data were collected from February to June 2012. They are part of a broader research project on factors of students' 
DRUŠ. ISTRAŽ. ZAGREB GOD. 25 (2016), BR. 4, STR. 503-522

PEČJAK, S., PIRC, T., PEKLAJ, C.

THE ROLE OF.. achievement in general upper secondary schools, which took place at the Department of Psychology University of Ljubljana from 2011 to 2012. All of the participants were informed about the purpose and methods of this study in February 2012. The participation was voluntary, but only students with written parental consent, which was ensured prior to data collection, were then included in the study. School psychologists were asked to form a list of students with codes assigned. They also carried out the application of the questionnaires from March to May 2012. Each student got a coded questionnaire, which was filled in during study courses: first, they responded to scales, measuring personality and specific motivational variables related to L1 and then to math. The completion of all the instruments took about 90 minutes. The students' L1 and math grades were obtained at the end of the school year in June 2012, and were recorded in the code list by the school psychologists as well.

\section{RESULTS AND DISCUSSION}

The relationships between personality traits, subject-specific motivational variables and students' achievement in math and L1

In Table 1, Pearson and Spearman correlation coefficients between different personality traits, subject-specific motivational dimensions and students' achievement, and descriptive data for all variables in two subjects are presented. In Tables 2 and 3 the estimations of the predictive power of personality and motivational variables on students' achievement with hierarchical regression analysis are presented.

Table 1 shows slightly lower (inter)correlations between the BFI factors than reported by other authors (Avsec \& Sočan, 2007; Shams et al., 2011), but some similar trends are apparent. In general, the comparison of connections between the personality dimensions and motivational processes and success in both subjects show more differences than similarities.

Among the students in both subjects, the following similarities were found: agreeableness, conscientiousness, energy and openness are significantly positively related to immediate action, but neuroticism is negatively correlated to it. In both subjects, students that were more cooperative, active, engaged and had more sense of duty, started with their activities much earlier. Furthermore, conscientiousness was significantly correlated with interest, self-efficacy, and final grades. More conscientious and caring students showed a higher interest in content material, perceived themselves as more self-effective and were also more successful. 


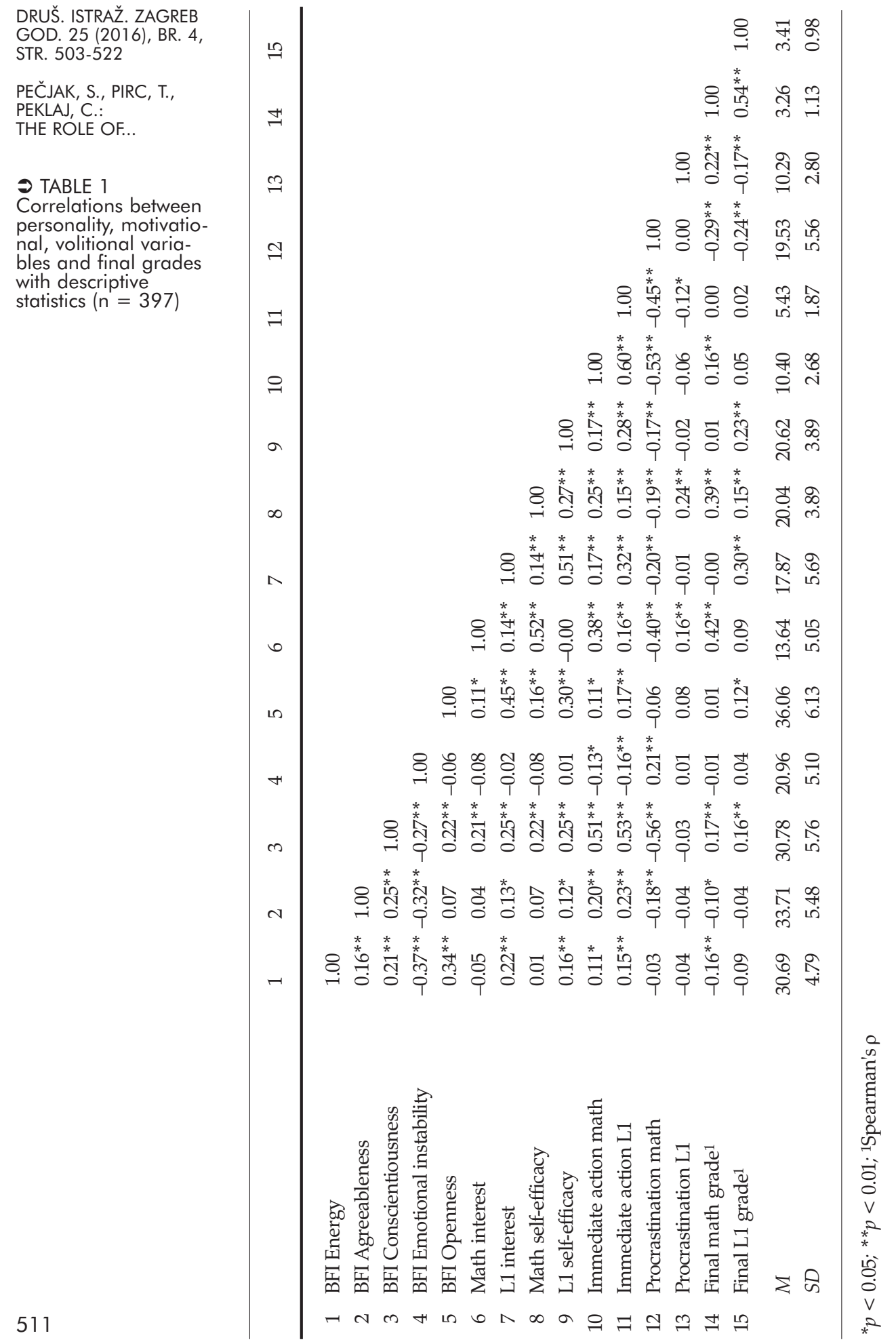


DRUŠ. ISTRAŽ. ZAGREB GOD. 25 (2016), BR. 4, STR. 503-522

PEČJAK, S., PIRC, T., PEKLAJ, C. THE ROLE OF.

There were, however, considerable differences found between subjects. Significant positive correlations in L1 were found between students' extraversion and agreeableness, and their motivation (interest and self-efficacy). Active, dynamic and more emphatic students showed significantly higher interest and felt more self-effective for L1. In math, conscientiousness and agreeableness were significantly negatively related with procrastination and positively with neuroticism. We also found that students procrastinate with assignments significantly less in L1 then in math. Again, this may indicate that the learning context in both subjects is different and leads to different student behaviour.

\section{Predictors of students' achievement in math and L1}

Due to several differences found in the relationships between personality and motivational dimensions in both subjects, we were further interested in the predictive power of these variables on students' achievement. Hierarchical regression analysis was used to estimate the predictive power of personality and motivational variables on students' achievement in math and L1.

We included personality factors in the first step of the

(1) TABLE 2

Hierarchical regression of BFI factors motivational factors and volitional strategies factors for achievement in math hierarchical regression analysis, motivational factors in the second and two volitional strategies in the third step. The results for L1 are presented in Table 2 and for math in Table 3.

\begin{tabular}{lccc}
\hline Predictors & Step $1(\beta)$ & Step 2 $(\beta)$ & Step 3 $(\beta)$ \\
\hline Energy & $-0.21^{* *}$ & $-0.15^{* *}$ & $-0.14^{*}$ \\
Agreeableness & $-0.17^{* *}$ & $-0.17^{* *}$ & $-0.17^{* *}$ \\
Conscientiousness & $0.24^{* * *}$ & $0.14^{* *}$ & 0.10 \\
Emotional instability & -0.08 & -0.04 & -0.03 \\
Openness & 0.01 & -0.06 & -0.05 \\
Interest & & $0.35^{* * *}$ & $0.32^{* * *}$ \\
Self-efficacy & & $0.19^{* *}$ & $0.20^{* * *}$ \\
Immediate action & & & -0.05 \\
Procrastination/distractibility & & & $-0.13^{*}$ \\
& & & \\
$R^{2}$ & 0.10 & 0.30 & 0.31 \\
adj. $R^{2}$ & 0.08 & 0.29 & 0.29 \\
$\Delta R^{2}$ & 0.10 & 0.20 & 0.01 \\
$\Delta F$ for $R^{2}(d f 1, d f 2)$ & $6.98(5,333)^{* * *}$ & $49.24(2,331)^{* * *}$ & $2.09(2,329)$ \\
\end{tabular}

Note. $N=397 ; \beta$ - standardized beta coefficient; $R^{2}$ - determinant multiple correlation coefficient; $\Delta R^{2}$ - multiple correlation coefficient change; adj. $R^{2}$ - adjusted multiple correlation coefficient; $F-$ F-ratio; $d f$ - degrees of freedom.

${ }^{*} p<0.05 ;{ }^{* *} p<0.01 ;{ }^{* *} p<0.001$ 


\begin{tabular}{lccc}
\hline Predictors & Step $1(\beta)$ & Step 2 $(\beta)$ & Step 3 $(\beta)$ \\
\hline Energy & $-0.14^{*}$ & $-0.16^{* *}$ & $-0.15^{* *}$ \\
Agreeableness & -0.08 & $-0.11^{*}$ & -0.09 \\
Conscientiousness & $0.18^{* *}$ & $0.12^{*}$ & $0.19^{* *}$ \\
Emotional instability & -0.03 & -0.01 & 0.00 \\
Openness & $-0.14^{*}$ & 0.02 & 0.00 \\
Interest & & $0.23^{* *}$ & $0.26^{* *}$ \\
Self-efficacy & & $0.12^{*}$ & $0.13^{*}$ \\
Immediate action & & & $0.17^{* * *}$ \\
Procrastination/distractibility & & & $-0.14^{*}$ \\
$R^{2}$ & 0.07 & 0.14 & 0.18 \\
adj. $R^{2}$ & 0.05 & 0.12 & 0.16 \\
$\Delta R^{2}$ & 0.07 & 0.07 & 0.04 \\
$\Delta F$ for $R^{2}(d f 1, d f 2)$ & $4.91(5,351)^{* * *}$ & $14.32(2,349)^{* * *}$ & $10.16(2,347)^{* * *}$ \\
\hline
\end{tabular}

Note. $N=397 ; \beta$ - standardized beta coefficient; $R^{2}$ - determinant multiple correlation coefficient; $\Delta R^{2}$ - multiple correlation coefficient change; adj. $R^{2}$ - adjusted multiple correlation coefficient; $F$ - F-ratio; $d f$ - degrees of freedom.

${ }^{*} p<0.05 ;{ }^{* *} p<0.01 ;{ }^{* *} p<0.001$

( TABLE 3

Hierarchical regression of BFI factors, motivational factors and volitional strategies factors for achievement in L1
With personality traits $7 \%$ of the variance in the student's final grade in L1 could be explained, with two motivational factors an additional 7\%, and with volitional strategies another $4 \%$ of the variance could be explained. In total, $18 \%$ of the variance in students' final grade in L1 could be explained. In math, however, the significant predictors were personality and motivational dimensions only. In the math final grade, $10 \%$ of the variance could be explained with personality traits, with motivational factors an additional $20 \%$, and only $1 \%$ with volitional strategies. Together, we were able to explain $31 \%$ of the variance in students' math achievement. Furthermore, both predictive models, in L1 as well as in math, could be generalised to the entire population of the first year of general upper secondary education students, because the differences between $R^{2}$ and adjusted $R^{2}$ are small in both subjects (by L1 and by math 0.02). These values show that with the selected personality, motivational and volitional variables only $2 \%$ more of the variance in learning achievement in L1 and in math could be explained in the entire population than we were able to explain in our sample of students.

A more thorough overview of the academic achievement predictors in L1 showed that the students' achievement could mostly be attributed to interest, conscientiousness, immediate action and self-efficacy. Conscientiousness, preciseness, persistence, specific interest, self-efficacy and immediate engagement in assignments lead to better academic achievement. Negative predictors for achievement in L1, however, were ener- 
DRUŠ. ISTRAŽ. ZAGREB GOD. 25 (2016), BR. 4, STR. 503-522

PEČJAK, S., PIRC, T., PEKLAJ, C. THE ROLE OF.. gy (more extravert and dynamic students had lower academic achievement) and procrastination/distractibility (poorer academic achievement was predicted by delaying learning activities, non-persistence in finishing assignments and problems with learning concentration).

Highly significant positive predictors of achievement in math (step 3) were interest and self-efficacy, while energy, agreeableness and procrastination were significantly negative predictors.

However, an interesting dynamic of changes in the predictive power of selected variables was found through each step. For example, conscientiousness was an important positive predictor of students' math achievement, but its predictive power decreased when motivational variables were included. Furthermore, when procrastination was added in the third step, conscientiousness was no longer a significant predictor. These results show that the role of students' personality traits in their learning achievement has to be interpreted along with interactional effects of motivational and volitional variables.

A similar outcome is evident in L1 with openness: by itself, this personality trait was an important negative predictor of students' learning achievement, but with interactional effects of motivational and volitional strategies, its power decreased and was no longer important for achievement in L1.

The most important positive predictors in both subjects proved to be motivational factors - interest and self-efficacy. Most authors emphasize the subject specificity of interest and self-efficacy (Caprara, Vecchione, Alessandri, Gerbino, \& Barbaranelli, 2011; Hidi, 2006; Hidi \& Renninger, 2006). In our study, we measured them with regard to specific contexts, and also found interest to be the strongest positive predictor of success in both subjects. The relation between interest and academic achievement was expected, because interest refers to a deep personal connection to the subject and willingness to re-engage in the domain over time (Schiefele, 2009). Furthermore, interest also includes positive feelings for the subject and the perception of the learning content's importance for an individual. This is also reflected in longer learning time (Alexander, Murphy, Woods, Duhon, \& Parker, 1997), in the activation of deep information processing strategies (Schiefele, 2001) and in enabling the connections with previous knowledge, which all lead to a better understanding of the learning material and higher achievement (Hidi \& Renninger, 2006).

The students' subject specific self-efficacy was an important positive predictor of academic achievement in both subjects. The significant relation between self-efficacy and success was expected for several reasons: first, we measured sub- 
DRUŠ. ISTRAŽ. ZAGREB GOD. 25 (2016), BR. 4 STR. 503-522

PEČJAK, S., PIRC, T. PEKLAJ, C.:

THE ROLE OF. ject specific self-efficacy in students (for math and L1) and established the predictive value for their achievement in the same subject, as suggested by Pajares (1996). Second, higher self-efficacy is an important "engine" of the students' learning motivation - it works through cognitive strategies and other motivational dimensions influencing their achievement (Hidi, 2006; Hidi \& Renninger, 2006). Third, students' learning achievement has a reverse effect on the consolidation of their beliefs about their abilities. By this experience, a positive connection between self-efficacy and achievement is established, which is strengthened in further learning situations. Therefore, we find it important to offer the fulfilment of this basic need for competence in the classroom context. This could be provided by adequate teachers' feedback - positive and specific, with precise descriptions of what students should do to improve their work when they are not successful.

Significant negative predictors in both subjects were energy and procrastination. We propose that students who are more outgoing and occupied with peer relations probably have less time for learning, which could be reflected in lower grades. These results are consistent with previous research $(\mathrm{Pu}-$ klek Levpušček et al., 2013). In addition, students who delayed their work, postponed their assignments or got unsettled quickly by different distractors, had lower achievement in both subjects than their peers, which is consistent with the meta-analysis made by Steel (2007).

Some basic differences between the two subjects should also be pointed out: conscientiousness and immediate action were found to be significant positive predictors of achievement in L1. This indicates that working with a purpose, a plan and on a regular basis is very important not just in a well-structured domain such as mathematics or science, but also in L1 (Trautwein et al., 2009; Puklek Levpušček et al., 2013; Smrtnik Vitulić \& Zupančič, 2013). Namely, in L1, students meet a lot of very diverse assignments from the language and literature fields - listening, reading, writing and speaking. Compared to math, they have to "switch" between different activities considering the content (language and literature) and if they want to make progress, they have to carry out their assignments regularly.

Furthermore, we found agreeableness to be a significant negative predictor for achievement in math, which was stable also after including motivational and volitional variables. This suggests that friendly, generous and cooperative students have lower grades in math than their peers. The results are consistent with outcomes of other studies, which show the same direction of correlations between agreeableness and achievement in math or the GPA (Di Fabio \& Busoni, 2007). The reason might be that agreeableness increases the willing- 
DRUŠ. ISTRAŽ. ZAGREB GOD. 25 (2016), BR. 4, STR. 503-522

PEČJAK, S., PIRC, T., PEKLAJ, C. THE ROLE OF.. ness to invest more effort in social and not in academic goals (Vasalampi et al., 2014). Namely, in math students usually solve mathematical problems individually. They rarely have experiences of solving problems cooperatively at school. In Slovenia, math curriculum in the general upper secondary educational programme also seldom includes cooperative learning activities and one cannot expect students to "take advantage" of their friendliness and cooperativity in the learning process.

However, our results are not in line with the results of some other studies on relations between agreeableness and the GPA in the Slovene students' samples in primary education, which did not find a correlation between these two variables (Smrtnik Vitulić \& Zupančič, 2013; Valenčič Zuljan \& Kalin, 2010). These findings might be explained by the fact that we explored connections between agreeableness and achievement in a subject specific situation (math, but not in general) and in upper secondary instead of primary education.

In L1, agreeableness was found to be a weak negative predictor for achievement, but it was significant only by interaction with motivational variables.

With regard to our study hypotheses, the summary of the findings is as follows: (i) H1 could be partly confirmed conscientiousness was positively connected with achievement in both subjects, but had a stronger predictive power in math only until motivational and volitional variables were included, otherwise it was more significant for achievement in L1; (ii) we were able to entirely confirm $\mathrm{H} 2$ - negative correlations were found between agreeableness, energy and learning achievement in both subjects and they were stronger negative predictors for math achievement; (iii) $\mathrm{H} 3$ was also confirmed, while self-efficacy, interest and immediate action proved to be significant positive predictors of achievement and procrastination/distractibility was a negative predictor of academic achievement in both subjects.

\section{CONCLUSIONS}

Our findings lead to the conclusions that some personality and motivational characteristics are more stable and important in different subjects and in various learning contexts (energy and procrastination as negative and self-efficacy and interest as positive predictors), and the others are more subject-specific (conscientiousness and immediate action for L1; agreeableness in math). At the same time, the significance of the learning environment in which students can take advantage of certain personality characteristics more efficiently (e.g., agreeableness, if lessons are organized in accordance with cooperative learning guidelines for activities), also emerged. 
DRUŠ. ISTRAŽ. ZAGREB GOD. 25 (2016), BR. 4 STR. 503-522

PEČJAK, S., PIRC, T. PEKLAJ, C.:

THE ROLE OF.
Similarly, as McGeown et al. (2014), we found out that interest and self-efficacy are the most important predictors of student achievement and are more malleable than personality traits at the same time. Wang and Holcombe (2010) suggest that a teacher should use real life examples which increase students' interest and design activities to promote reflective, deep and critical thinking.

However, there were some limitations which should be taken into account when implementing the results of our study into practice. The first one refers to our sample. Namely, the findings about the roles of selected students' personality and motivational traits in their learning achievement are valid for the specific environment of upper secondary education. The second limitation is concerned with the use of self-report instruments, which require a certain level of self-awareness and honesty when answering.

Finally, we would like to emphasize the importance of further investigation of the roles of personality and motivational factors not only in individual subjects but also according to specific instruction characteristics and school culture as mediators. According to previous research, inconsistent results regarding connections between personality traits and students' learning achievement were found in all educational stages (from primary to tertiary education). We presume that the examination of these connections is more influenced by characteristics of a specific context (in specific subjects) and by the school culture in which the study takes place than by the students' age. If a traditional school culture with the emphasis on high students' achievement, ambitiousness, effort, etc. prevails, it could be assumed that a different pattern of the connections between students' personality characteristics and their achievement will be revealed in comparison with a school culture where the values of mutual acceptance, help and tolerance are appraised. Therefore, for future research we suggest an investigation of effects of students' personality and motivational characteristics on their learning achievement by controlling the school culture factors.

\section{REFERENCES}

Alexander, P. A., Murphy, P. K., Woods, B. S., Duhon, K. E., \& Parker, D. (1997). College instruction and concomitant changes in students' knowledge, interest, and strategy use: A study of domain learning. Contemporary Educational Psychology, 22(2), 125-146. https://doi.org/ 10.1006/ceps.1997.0927

Avsec, A., \& Sočan, G. (2007). Vprašalnik petih velikih faktorjev BFI (The Big Five Inventory BFI). In A. Avsec (Ed.), Psihodiagnostika osebnosti (Psychodiagnostics of personality) (pp. 171-178). Ljubljana: Filozofska fakulteta UL. 
DRUŠ. ISTRAŽ. ZAGREB GOD. 25 (2016), BR. 4, STR. 503-522

PEČJAK, S., PIRC, T., PEKLAJ, C. THE ROLE OF..
Bandura, A. (1986). Social foundation of thought and action: A social cognitive theory. Englewood Cliffs: Prentice Hall.

Bratko, D., Chamorro-Premuzic, T., \& Saks, Z. (2006). Personality and school performance: Incremental validity of self- and peer-ratings over intelligence. Personality and Individual Differences, 41(1), 131-142. https://doi.org/10.1016/j.paid.2005.12.015

Caprara, G. V., Vecchione, M., Alessandri, G., Gerbino, M., \& Barbaranelli, C. (2011). The contribution of personality traits and self-efficacy beliefs to academic achievement: A longitudinal study. British Journal of Educational Psychology, 81(1), 78-96. https://doi.org/10.1348/ 2044-8279.002004

Chamorro-Premuzic, T., \& Furnham, A. (2003). Personality predicts academic performance: Evidence from two longitudinal university samples. Journal of Research in Personality, 37(4), 319-338. https://doi. org/10.1016/S0092-6566(02)00578-0

Chamorro-Premuzic, T., \& Furnham, A. (2005). Personality and intellectual competence. New Jersey: LEA.

Conard, M. A. (2006). Aptitude is not enough. How personality and behaviour predict academic performance. Journal of Research in Personality, 40(3), 339-346. https://doi.org/10.1016/j.jrp.2004.10.003

Corno, L. (2001). Volitional aspects of self-regulated learning. In B. J. Zimmerman, \& D. H. Schunk (Eds.), Self-regulated learning and academic achievement. Theoretical perspectives (pp. 191-226). Mahwah: Lawrence Erlbaum Associates.

De Feyter, T., Caers, R., Vigna, C., \& Berings, D. (2012). Unravelling the impact of the Big Five personality traits on academic performance: The moderating and mediating effects of self-efficacy and academic motivation. Learning and Individual Differences, 22(4), 439-448. https://doi. org/10.1016/j.lindif.2012.03.013

De Raad, B., \& Schouwenburg, H. C. (1996). Personality in learning and education: A review. European Journal of Personality, 10(5), 303-336. https://doi.org/10.1002/(SICI)1099-0984(199612)10:5<303::AID-PER $262>3.0 . \mathrm{CO} ; 2-2$

Di Fabio, A., \& Busoni, L. (2007). Fluid intelligence, personality traits and scholastic success: Empirical evidence in a sample of Italian high school students. Personality and Individual Differences, 43(8), 2095-2104. https://doi.org/10.1016/j.paid.2007.06.025

Furham, A., Monsen, J., \& Ahmetoglu, G. (2009). Typical intellectual engagement, Big Five personality traits, approaches to learning and cognitive ability predictors of academic performance. British Journal of Educational Psychology, 79(4), 769-782. https://doi.org/10.1348/97818 5409X412147

Guthrie, J. T., Wigfield, A., Metsala, J. L., \& Cox, K. E. (1999). Motivational and cognitive predictors of text comprehension and reading amount. Scientific Studies of Reading, 3(3), 231-256. https://doi.org/10.1207/s153 2799xssr0303_3

Hair, P., \& Hampson, S. E. (2006). The role of impulsivity in predicting maladaptive behaviour among female students. Personality and 
DRUŠ. ISTRAŽ. ZAGREB GOD. 25 (2016), BR. 4 STR. 503-522

PEČJAK, S., PIRC, T. PEKLAJ, C.:

THE ROLE OF.
Individual Differences, 40(5), 943-952. https://doi.org/10.1016/j.paid.2005. 10.002

Hidi, S. (2001). Interest, reading, and learning: Theoretical and practical considerations. Educational Psychology Review, 13(3), 191-209. https://doi.org/10.1023/A:1016667621114

Hidi, S. (2006). Interest: A unique motivational variable. Educational Research Review, 1(2), 69-82. https://doi.org/10.1016/j.edurev.2006.09.001

Hidi, S., \& Renninger, A. K. (2006). The four-phase model of interest development. Educational Psychologist, 41(2), 111-127. https://doi.org/ $10.1207 / \mathrm{s} 15326985$ ep4102_4

John, O. P., Donahue, E. M., \& Kentle, R. L. (1991). The "Big Five" Inventory-Versions $4 a$ and 54 . Berkley: University of California, Berkley, Institute of Personality and Social Research.

Kenney-Benson, G. A., Pomerantz, E. M., Ryan, A. M., \& Patrick, H. (2006). Sex differences in math performance: The role of children's approach to schoolwork. Psychology, 42(1), 11-26. https://doi.org/10. 1037/0012-1649.42.1.11

Klassen, R. M., Krawchuk, L. L., \& Rajani, S. (2008). Academic procrastination of undergraduates: Low self-efficacy to self-regulate predicts higher levels of procrastination. Contemporary Educational Psychology, 33(4), 915-931. https://doi.org/10.1016/j.cedpsych.2007.07.001

Köller, O., Baumert, J., \& Schnabel, K. (2001). Does interest matter? The relationship between academic interest and achievement in mathematics. Journal of Research in Mathematics Education, 32(5), 448-470. https://doi.org/10.2307/749801

Komarraju, M., Karau, S. J., \& Schmeck, R. R. (2009). Role of the Big Five personality traits in predicting college student's academic motivation and achievement. Learning and Individual Differences, 19(1), 47-52. https://doi.org/10.1016/j.lindif.2008.07.001

Kuhl, J., \& Fuhrmann, A. (2004). Self-Regulation-Inventory: SSI-K3 (Short Version): Scoring Key. Unpublished material. University of Osnabrück.

Laidra, K., Pullmann, H., \& Allik, J. (2007). Personality and intelligence as predictors of academic achievement: A cross-sectional study from elementary to secondary school. Personality and Individual Differences, 42(3), 441-451. https://doi.org/10.1016/j.paid.2006.08.001

Liem, A. D., Lau, S., \& Nie, Y. (2008). The role of self-efficacy, task value, and achievement goals in predicting learning strategies, task disengagement, peer relationship, and outcome. Contemporary Educational Psychology, 33(4), 486-512. https://doi.org/10.1016/j.cedpsych. 2007.08.001

Lipnevich, A. A., MacCann, S., Krumm, C., Burrus, J., \& Roberts, R. D. (2011). Mathematics attitudes and mathematics outcomes of U.S. and Belarusian middle school students. Journal of Educational Psychology, 103(1), 105-118. https://doi.org/10.1037/a0021949

McCrea, R. R., \& Costa, P. T. Jr. (1999). Five factor theory of personality. In L. A. Parvin, \& O. P. John (Eds.), Handbook of personality: Theory and research (pp. 139-153). New York: Guilford Press.

McGeown, S., Putwain, D., Geijer Simpson, E., Boffey, E., Markham, J., \& Vince, A. (2014). Predictors of adolescents' academic motivation: 
DRUŠ. ISTRAŽ. ZAGREB GOD. 25 (2016), BR. 4, STR. 503-522

PEČJAK, S., PIRC, T., PEKLAJ, C. THE ROLE OF..
Personality, self-efficacy and adolescents' characteristics. Learning and Individual Differences, 32(4), 278-286. https://doi.org/10.1016/j.lindif. 2014.03.022

Midgley, C., Maehr, M. L., Hruda, L. Z., Anderman, E., Anderman, L., Freeman, K. E. et al. (2000). Manual for the Patterns of Adaptive Learning Scale. Michigan: The University of Michigan.

Pajares, F. (1996). Self-efficacy beliefs in academic settings. Review of Educational Research, 66(4), 543-578. https://doi.org/10.3102/003465430 66004543

Pečjak, S., Bucik, N., Gradišar, A., \& Peklaj, C. (2006). Bralna motivacija $v$ šoli: merjenje in razvijanje (Reading motivation in school: Measuring and developing). Ljubljana: Zavod Republike Slovenije za šolstvo.

Pečjak, S., Kolić Vehovec, S., \& Podlesek, A. (2014). Models of reading comprehension for primary school students. In A. Galmonte, \& R. Actis-Grosso (Eds.), Different psychological perspectives on cognitive processes: Current research trends in Alps-Adria region (pp. 309-334). Newcastle upon Tyne: Cambridge Scholars Publishing.

Peklaj, C., Podlesek, A., \& Pečjak, S. (2015). Gender, previous knowledge, personality traits and subject-specific motivation as predictors of students' math grade in upper-secondary school. European Journal of Psychology of Education, 30(3), 313-330. https://doi.org/10.1007/s10 212-014-0239-0

Peklaj, C., \& Vodopivec, B. (1998). Metacognitive, affective-motivational processes and student achievement in mathematics. Studia Psychologica, 40(3), 197-209.

Poropat, A. E. (2009). A meta-analysis of the five-factor model of personality and academic performance. Psychological Bulletin, 135(2), 322-338. https://doi.org/10.1037/a0014996

Puklek Levpušček, M., \& Zupančič, M. (2009). Math achievement in early adolescence: The role of parental involvement, teachers' behaviour and students' motivational beliefs about math. Journal of Early Adolescence, 29(4), 541-570. https://doi.org/10.1177/0272431608324189

Puklek Levpušček, M., Zupančič, M., \& Sočan, G. (2013). Predicting achievement in mathematics in adolescent students: The role of individual and social factors. Journal of Early Adolescence, 33(4), 523-551. https://doi.org/10.1177/0272431612450949

Schiefele, U. (2001). The role of interest in motivation and learning. In J. M. Collis, \& S. Messick (Eds.), Intelligence and personality: Bridges the gap in theory and measurement (pp. 163-194). Mahwah, NJ: Erlbaum.

Schiefele, U. (2009). Situational and individual interest. In K. R. Wentzel, \& A. Wigfield, Handbook of motivation at school (pp. 197-222). New York and London: Routledge.

Schiefele, U., Krapp, A., \& Winteler, A. (1992). Interest as a predictor of academic achievement: A meta-analysis of research. In K. A. Renninger, S. Hidi, \& A. Krapp (Eds.), The role of interest in learning and development (pp. 183-212). Hillsdale, MJ: Lawrence Erlbaum Associates. 
DRUŠ. ISTRAŽ. ZAGREB GOD. 25 (2016), BR. 4 STR. 503-522

PEČJAK, S., PIRC, T., PEKLAJ, C.:

THE ROLE OF.
Schunk, D. H., \& Zimmerman, B. J. (2007). Influencing children's self-efficacy and self-regulation of reading and writing through modelling. Reading $\mathcal{E}$ Writing Quarterly, 23(1), 7-25. https://doi.org/10. 1080/10573560600837578

Shams, F., Mooghali, A. R., Tabebordbar, F., \& Soleimanpour, N. (2011). The mediating role of academic self-efficacy and the relationship between personality traits and mathematic performance. Procedia - Social and Behavioral Sciences, 29, 1689-1692. https://doi.org/10. 1016/j.sbspro.2011.11.413

Smrtnik Vitulić, H., \& Zupančič, M. (2013). Robust and specific personality traits as predictors of adolescents' final grades and GPA at the end of compulsory schooling. European Journal of Psychology of Education, 28(4), 1181-1199. https://doi.org/10.1007/s10212-012-0161-2

Steel, P. (2007). The nature of procrastination: A meta-analytic and theoretical review of quintessential self-regulatory failure. Psychological Bulletin, 133(1), 65-94. https://doi.org/10.1037/0033-2909.133.1.65

Taštanoska, T. (Ed.) (2014). Vzgoja in izobraževanje v Republiki Sloveniji (Education in Slovenia). Ljubljana: MIZŠ.

Trautwein, U., Lüdtke, O., Roberts, B. W., Schnyder, I., \& Niggli, A. (2009). Different forces, same consequence: Conscientiousness and competence beliefs are independent predictors of academic effort and achievement. Journal of Personality and Social Psychology, 97(6), 1151-1128. https://doi.org/10.1037/a0017048

Tulis, M., \& Fulmer, S. M. (2013). Students' motivational and emotional experiences and their relationship to persistence during academic challenge in mathematics and reading. Learning and Individual Differences, 27, 35-46. https://doi.org/10.1016/j.lindif.2013.06.003

Učni načrt. Matematika: gimnazija: splošna, klasična in strokovna gimnazija [Curriculum for Mathematics] (2008). Ljubljana: Ministrstvo za šolstvo in šport, Zavod RS za šolstvo. Available at http://www.mss.gov. si/fileadmin/mss.gov.si/pageuploads/podrocje/ss/programi/2008/Gim nazije/UN_MATEMATIKA_gimn.pdf.

Učni načrt. Slovenščina: gimnazija: splošna, klasična, strokovna gimnazija [Curriculum for Slovene language] (2008). Ljubljana: Ministrstvo za šolstvo in šport, Zavod RS za šolstvo. Available at http://www.mss.gov. si/fileadmin/mss.gov.si/pageuploads/podrocje/ss/programi/2008/Gim nazije/UN_SLOVENSCINA_gimn.pdf.

Valenčič Zuljan, M., \& Kalin, J. (2010). Effectiveness and competency of teachers in terms of student's assessment of teacher's conduct. In C. Peklaj (Ed.), Teacher competencies and educational goals (pp. 9-36). Schriften zur Bildungs-und Freizeitwissenschaft, Band 6. Aachen: Shaker Verlag.

Vasalampi, K., Parker, P., Tolvanen, A., Lüdke, O., Salmela-Aro, K., \& Trautwein, U. (2014). Integration of personality constructs: The role of traits and motivation in the willingness to exert effort in academic and social life domains. Journal of Research in Personality, 48, 98-106. https://doi.org/10.1016/j.jrp.2013.11.004

Walker, C. O., Greene, B. A., \& Mansell, R. A. (2006). Identification with academics, intrinsic/extrinsic motivation, and self-efficacy as 
DRUŠ. ISTRAŽ. ZAGREB GOD. 25 (2016), BR. 4, STR. 503-522

PEČJAK, S., PIRC, T., PEKLAJ, C.

THE ROLE OF.. predictors of cognitive engagement. Learning and Individual Differences, 16(1), 1-12. https://doi.org/10.1016/j.lindif.2005.06.004

Wang, M., \& Holcombe, R. (2010). Adolescents' perceptions of school environment, engagement, and academic achievement in middle school. American Educational Research Journal, 47(3), 633-662. https://doi. org/10.3102/0002831209361209

Wolters, C. A., \& Rosenthal, H. (2000). The relation between students' motivational beliefs and their use of motivational regulation strategies. International Journal of Educational Research, 33(7-8), 801-820. https://doi.org/10.1016/S0883-0355(00)00051-3

\section{Uloga ličnosti i predmetno specifične motivacije na uspieh učenika u matematici i materinskom jeziku}

Sonja PEČJAK, Tina PIRC, Cirila PEKLAJ

Filozofski fakultet, Ljubljana

Svrha je istraživanja bila proučiti odnose između osobina ličnosti, predmetno specifičnih motivacijskih dimenzija i uspjeha učenika u srednjoj školi u matematici i materinskom jeziku te utvrditi kako te varijable prognoziraju njihova dostignuća. U istraživanju je sudjelovalo 397 učenika prvog razreda srednjih škola u Sloveniji. Primijenjeni su različiti postupci za utvrđivanje osobina ličnosti učenika, predmetno specifičnoga interesa, samoučinkovitosti, strategija volje i završne ocjene učenika iz matematike i materinskoga jezika. Rezultati istraživanja pokazali su različit uzorak i prognostičku snagu uključenih varijabli na uspjeh učenika u oba predmeta. Uključene varijable objasnile su $18 \%$ razlika između učenika u slovenskom jeziku i 31\% razlika između učenika u matematici. Kod oba predmeta uspjeh učenika značajno su pozitivno prognozirali samoučinkovitost $i$ interes, a značajno negativno energija i odgađanje. U matematici je značajan negativni prognostički pokazateli bila ljubaznost, a u slovenskom jeziku pozitivni prognostički pokazatelii uspješnosti učenika bili su savjesnost $i$ trenutačno reagiranje. $U$ članku se ističu i implikacije rezultata istraživanja.

Ključne riječi: osobine ličnosti, interes, samoučinkovitost, učenici, uspjeh

\section{(c) (i) $\odot$}

Međunarodna licenca / International License:

Creative Commons Attribution-NonCommercial-NoDerivatives 4.0. 